\title{
DESAIN DATABASE SISTEM INFORMASI PENERIMAAN PESERTA DIDIK BARU PADA SELECTIVE ENGLISH COURSE
}

\author{
Anisah \\ Program Studi Sistem Informasi \\ STMIK Atma Luhur \\ Email: anisah@atmaluhur.ac.id \\ Melati Suci Mayasari \\ Program Studi Manajemen Informatika \\ STMIK Atma Luhur \\ Email: imeal_melati@atmaluhur.ac.id
}

\begin{abstract}
ABSTRAK
Sistem penerimaan peserta didik baru yang ada pada Selective English Course pada saat ini, untuk pengolahan datanya masih menggunakan sistem yang manual dan belum menggunakan sebuah sistem yang terkomputerisasi. Adapun proses bisnis sistem yang berjalan saat ini meliputi proses pendaftaran dan pembayaran pendaftaran, proses placement test, proses pemilihan jadwal, dan proses pembuatan laporan pedik (Peserta Didik). Dalam penelitian ini, akan menganalisa sistem yang berjalan dan menggambarkan proses bisnis yang ada dengan menggunakan diagram UML (Unified Modelling Language) yaitu Activity Diagram. Berdasarkan hasil analisa terhadap sistem yang berjalan yang tergambarkan dalam Activity Diagram tersebut, kemudian melakukan desain database berdasarkan data yang ada dengan menggunakan model data Entity Relationship yaitu dengan menggunakan Entity Relationship Diagram (ERD). Dengan adanya proses desain database ini, pengolahan data yang sebelumnya masih menggunakan sistem manual bisa ditingkatkan menjadi pengolahan data secara terkomputerisasi. Sehingga dengan adanya sebuah sistem yang terkomputerisasi, kebutuhan akan informasi dapat dihasilkan dengan lebih cepat, tepat dan akurat dan proses pengambilan keputusan dapat dilakukan secara cepat dan efektif.
\end{abstract}

Kata kunci: database, unified modelling language, entity relationship diagram.

\begin{abstract}
At this time students admission system existing on Selective English Course for data processing still using manual system not computerized. Current academic system covers registration processes and registration payment, placement test process, schedule selecting process, and PEDIK (students) reporting process. In this research, the authors will analyze and describe existing business processes system using Activity Diagram and UML diagrams (Unified Modeling Language). Based on running system analyzing result in Activity Diagram, then the authors make database design based on existing data using Entity Relationship data in Entity Relationship Diagram (ERD). By using this database design, data processing that previously using manual system can be upgraded to computerized data processing. We expect by using computerized system, information requirement can be accomplish quicker and accurate, and the decision making process can be done quickly and effectively.
\end{abstract}

Keywords: database, unified modelling language diagram, entity relationship diagram.

\section{PENDAHULUAN}

Selective English Course merupakan Lembaga Kursus dan Pelatihan (LKP) yang ada dalam bimbingan dan pengawasan Dinas Pendidikan yang berstatus lembaga pendidikan non formal. Penerimaan peserta didik pada LKP Selective English Course ini merupakan kegiatan penting untuk LKP dimana kegiatan tersebut sering dilakukan jika ada peserta didik yang mendaftar kursus pada LKP tersebut.

Pengolahan data yang ada pada Selective English Course pada saat ini masih menggunakan sistem manual mulai dari proses pendaftaran dan pembayaran pendaftaran, proses placement test, proses pemilihan jadwal, dan proses pembuatan laporan pedik (Peserta Didik). Berdasarkan hasil analisa terhadap sistem yang berjalan terdapat permasalahan diantaranya adalah data-data yang berkaitan denga $\mathrm{n}$ penerimaan peserta didik baru belum disimpan secara rapi, sehingga membutuhkan waktu yang lama pada saat ingin menemukan kembali data yang berkaitan dengan peserta didik, selain itu, pembuatan laporan Pedik (Perserta Didik) membutuhkan waktu yang agak lama, sehingga dapat berpengaruh terhadap pengambilan keputusan yang akan diambil oleh pimpinan Selective English Course. Berdasarkan masalah yang ditemukan di atas, dirasakan perlu adanya sebuah sistem yang 
terkomputerisasi dengan harapan, proses pengolahan data yang masih menggunakan sistem yang manual dapat ditingkatkan menjadi sebuah sistem yang terkomputerisasi dengan terlebih dahulu melakukan desain database berdasarkan data yang berkaitan dengan sistem penerimaan peserta didik baru tersebut, sehingga dengan adanya desain database tersebut dapat mempermudah pengembang sistem untuk melanjutkan ke tahapan implementasi nantinya. Sehingga masalah-masalah yang ditemukan pada sistem yang berjalan tersebut dapat teratasi.

Berdasarkan hasil penelitian sebelumnya yang berjudul :" Perancangan Sistem Informasi Penerimaan Siswa baru Pada Sekolah Menengah Kejuruan Negri 3 Pacitan[1]. dimana peneliti membahas mengenai pelaksanaan kegiatan penerimaan siswa baru tersebut masih menggunakan sistem yang manual, sehingga sering mengalami permasalahan, sehingga diusulkan sebuah sistem informasi berbasis komputerisasi dan aplikasi basis data untuk membantu penyampaian infomasi dan mempermudah dalam pelaksanaan pengolahan data yang berkaitan dengan penerimaan siswa baru tersebut.

Berdasarkan penelitian tersebut, akan dilakukan desain database untuk sistem penerimaan peserta didik yang ada pada Selective English Course tersebut sehingga pengolahan data yang dilakukan untuk saat ini yang masih manual bisa ditingkatkan menjadi sebuah sistem yang terkomputerisasi dengan harapan dapat mengatasi permasalah yang ada pada selective English Course tersebut.

Konsep dasar data dan informasi : Data dan informasi sering digunakan secara bergantian, data merupakan bentuk jamak dari bentuk tuggal datum. Data adalah kenyataan yang menggambarkan suatu kejadian-kejadian dan kesatuan nyata. Kejadian-kejadian adalah suatu yang terjadi pada saat tertentu di dalam dunia bisnis. Sumber dari informasi adalah data. Informasi merupakan data yang telah diproses ke dalam suatu bentuk yang mempunyai arti bagi si penerima dan mempunyai nilai nyata dan terasa bagi keputusan saat itu atau keputusan mendatang.[2]

Konsep dasar sistem dan sistem informasi: secara sederhana suatu sistem dapat diartikan sebagai suatu kumpulan atau himpunan dari unsur, komponen, atau variabel yang terorganisisr, saling berinteraksi, saling tergantung satu sama lain, dan terpadu. Sedangkan Sistem informasi adalah suatu sistem di dalam suatu organisasi yang mempertemukan kebutuhan pengolahan transaksi harian yang mendukung fungsi operasi organisasi yang bersifat manajerial dengan kegiatan strategi dari suatu organisasi untuk dapat menyediakan kepada pihak luar tertentu dengan laporan-laporan yang diperlukan.[2]

Pengertian basis data dapat didefinisikan sebagai berikut : Basis data adalah sekumpulan data yang saling berhubungan secara logis beserta deskripsinya, yang digunakan secara bersama-sama dan dirancang untuk memenuh kebutuhan informasi di suatu tempat.[3].

Pengertian Basis Data relational : Basis data relational adalah basis data yang merepresentasikan data dalam bentuk tabel-tabel, dimana tabel-tabel tersebut dihubungkan oleh nilai-nilai yang sama/umum pada kolom terkait.[3].

Pengertian database : "Database adalah kumpulan file-file yang saling berelasi, relasi tersebut ditunjukkan dengan kunci dari tiap file yang ada. Satu database menunjukkan satu kumpulan data yang dipakai dalam satu lingkup perusahaan atau instansi. DBMS berisi satu koleksi data yang saling berelasi dan satu set program untuk mengakses data tersebut"[4].

Pengertian peracncangan basis data dengan menggunakan model entity relationship : "Perancangan basis data dengan menggunakan model entity relationship adalah dengan menggunakan Entity Relationship Diagram(ERD)"'[5]. Terdapat 3 notasi dasar yang bekerja pada model ER yaitu : entity Set, relationship Set, dan attributes.

E-R Model didasarkan atas persepsi terhadap dunia nyata yang terdiri dari sekumpulan obyek, disebut entitas dan hubungan antar obyek tersebut disebut relasi. Entitas adalah objek di dunia yang bersifat unik. Setiap entitas mempunyai atribut yang membedakannya dengan entitas lainnya.

Pemodelan data dengan model E-R menggunakan Diagram E-R yang terdiri dari :, kotak persegi panjang yang menggambarkan himpunan entitas, elip menggambarkan atribut-atribut entitas, diamond menggambarkan hubungan antar himpunan entitas, dan garis yang menguhubungkan antar objek dalam diagram E-R. Model data Entity Relationship(model E-R) adalah model data yang pembuatannya didasarkan pada anggapan bahwa dunia nyata terdiri dari kumpulan objek dasar yang disebut entity dan relasi diantaranya.

Activity diagram menggambarkan proses bisnis dan urutan aktifitas dalam sebuah proses, yang mana dipakai pada business modelling untuk memperlihatkan urutan aktifitas proses bisnis karena bermanfaat untuk membantu memahami proses secara keseluruhan dalam memodelkan sebuah proses.

Activity diagram merupakan salah satu diagram yang terdapat dalam UML. "UML adalah bahasa standar yang digunakan untuk menjelaskan dan memvisualisasikan artifak dari proses analisis dan desain berorientasi obyek"[5]. 


\section{METODOLOGI PENELITIAN}

Untuk metodologi yang digunakan dalam penelitian ini dalam rangka mengumpulkan data yang diperlukan adalah sebagai berikut :

a. Dengan melakukan wawancara untuk mengetahui gambaran tentang Sistem penerimaan peserta didik baru yang ada pada Selective English Course.

b. Studi kepustakaan untu mencari materi/bahan/buku yang menunjang dan berkaitan dengan penelitian yang akan dilakukan sehingga dapat memberikan data secara teoritis.

c. Analisa sistem yang berjalan menggunakan Diagram UML yaitu Activity Diagram untuk mengetahui alur kerja dari sebuah proses bisnis dan urutan aktifitas dalam sistem penerimaan peserta didik yang ada pada Selective English Course .

d. Perancangan basis data menggunakan model Entity Relationship(model -ER) dengan menggunakan Entity Relationship Diagram (ERD).

\section{HASIL PENELITIAN DAN PEMABAHASAN}

Untuk proses yang terjadi pada sistem peserta didik baru yang ada pada Selective English Course mulai dari proses pendaftaran dan pembayaran pendaftaran, proses placement test, proses pemilihan jadwal, dan proses pembuatan laporan pedik (Peserta Didik) digambarkan dengan menggunakan diagram UML yaitu Activity Diagram. Adapun Activity Diagram dapat dilihat pada gambar di bawah ini :

a Proses Pendaftaran Dan Pembayaran Pendaftaran

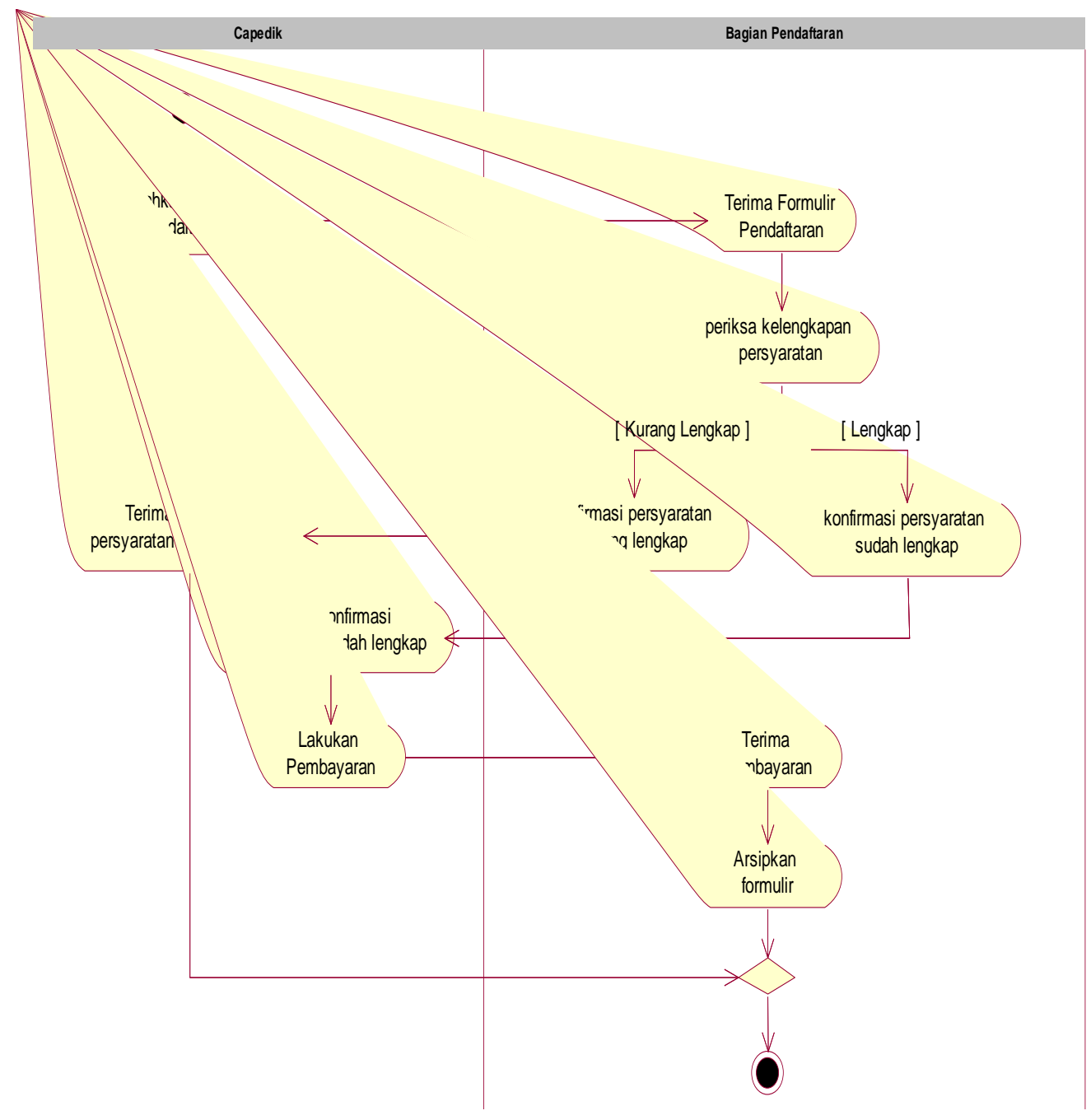

Gambar 1. Proses Pendaftaran Dan Pembayaran Pendaftaran 
b Proses Placement Test

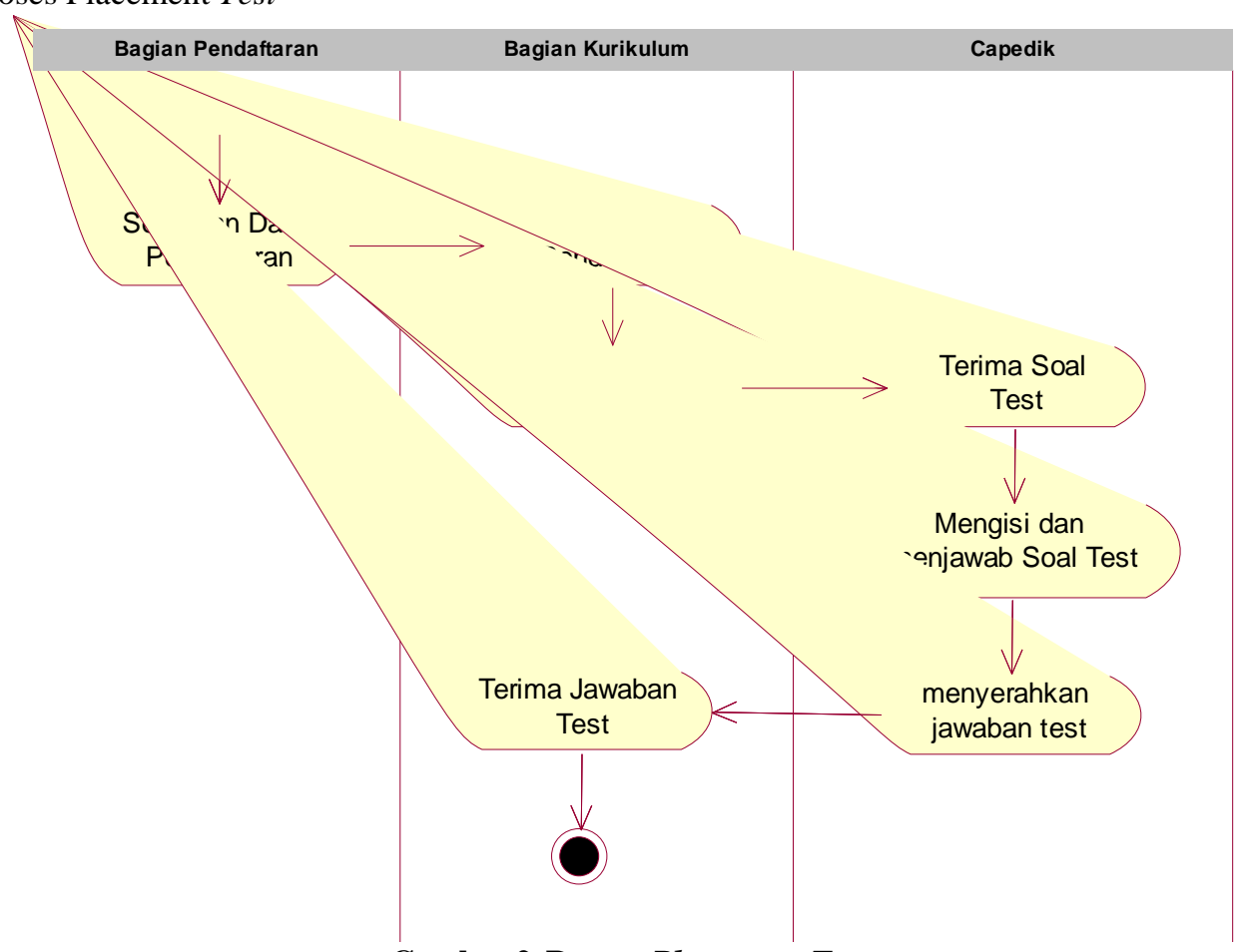

Gambar 2. Proses Placement Test

c Proses Pemilihan Jadwal Kursus

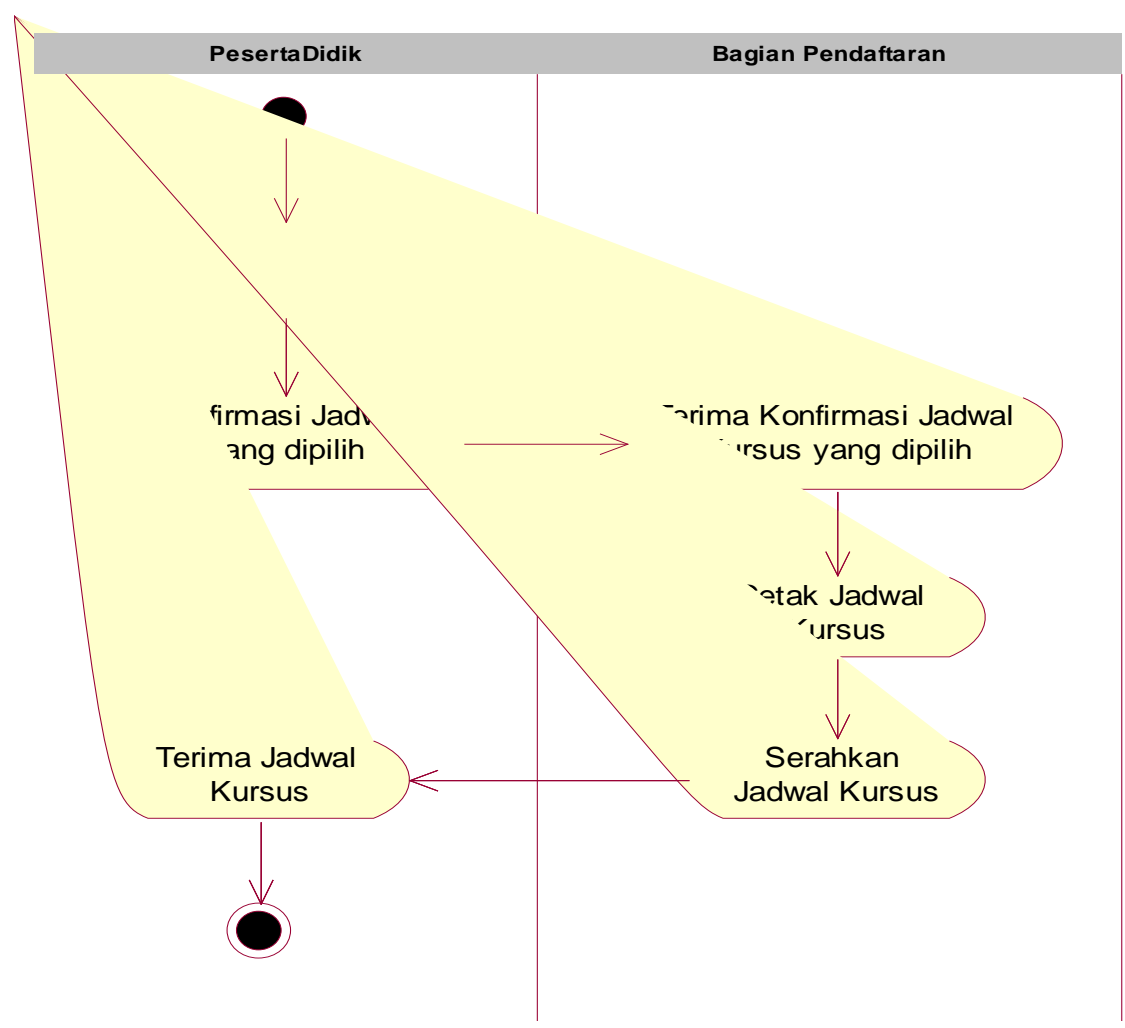

Gambar 3. Proses Pemilihan Jadwal Kursus 
d Proses Laporan Peserta Didik

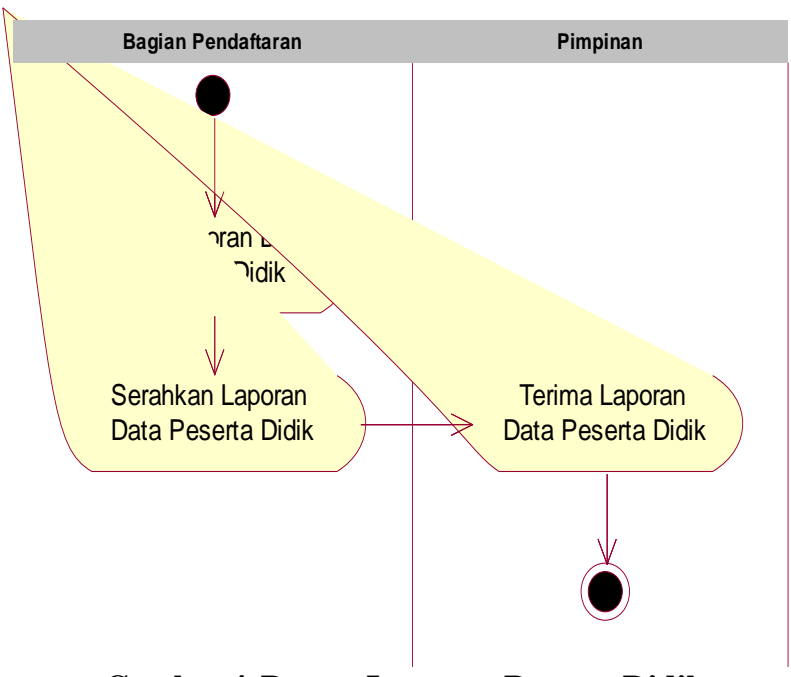

Gambar 4. Proses Laporan Peserta Didik

Setelah dilakukan analisa terhadap proses yang berjalan yang masih menggunakan sistem manual, kemudian akan dirancang basis data sesuai dengan kebutuhan yang ada pada Selective English Course. Adapun rancangan basis datanya mulai dari Entity Relationship Diagram, Transformasi Entity Relationship Diagram ke Logical Record Structure, tabel-tabel, dan skema relasi yang dihasilkan yang dapat dilihat pada gambar di bawah ini :

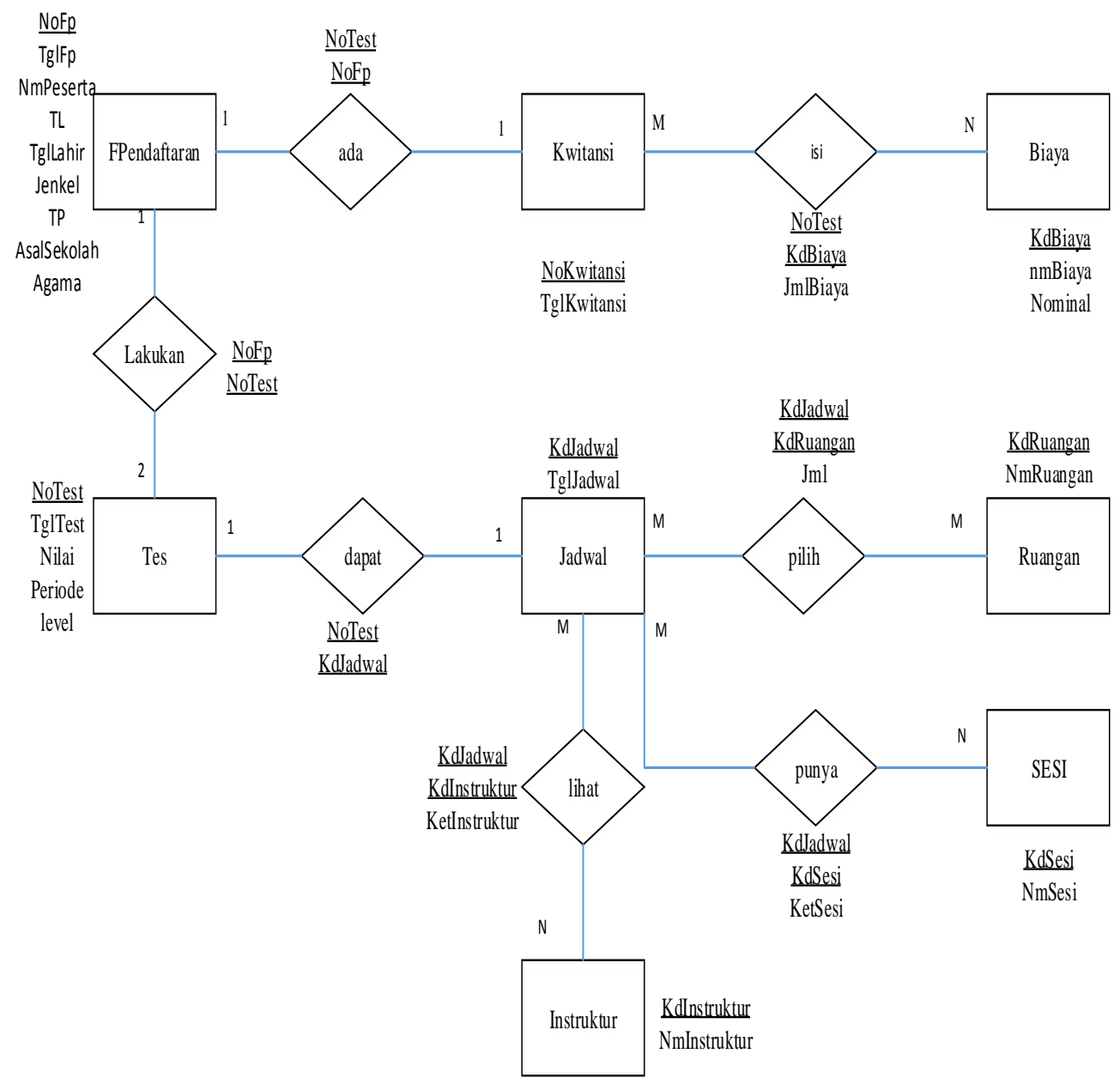

Gambar 5. Entity Relationship Diagram 


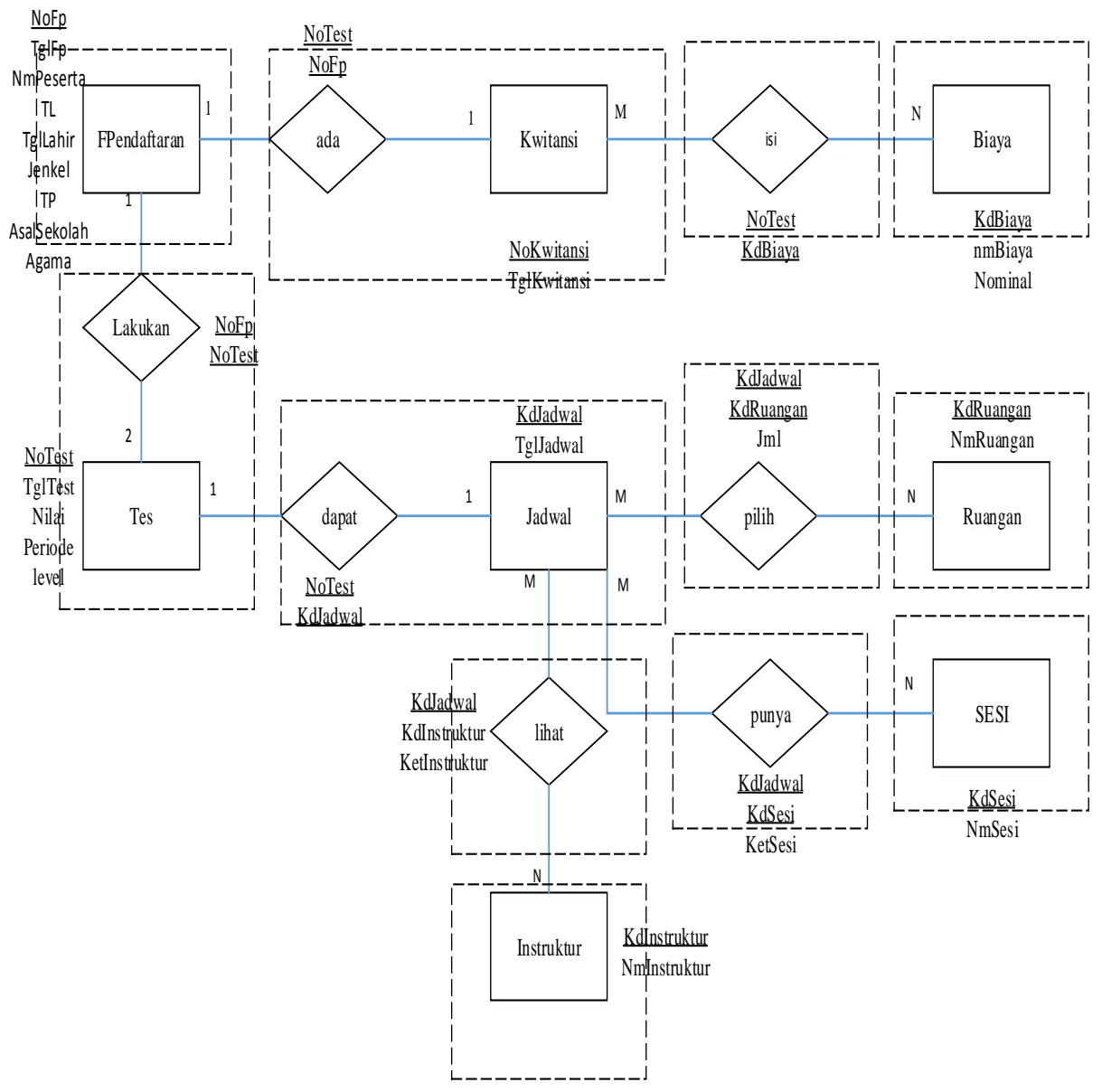

\section{Gambar 6. Transformasi Entity Relationship Diagram ke Logical Record Structure}

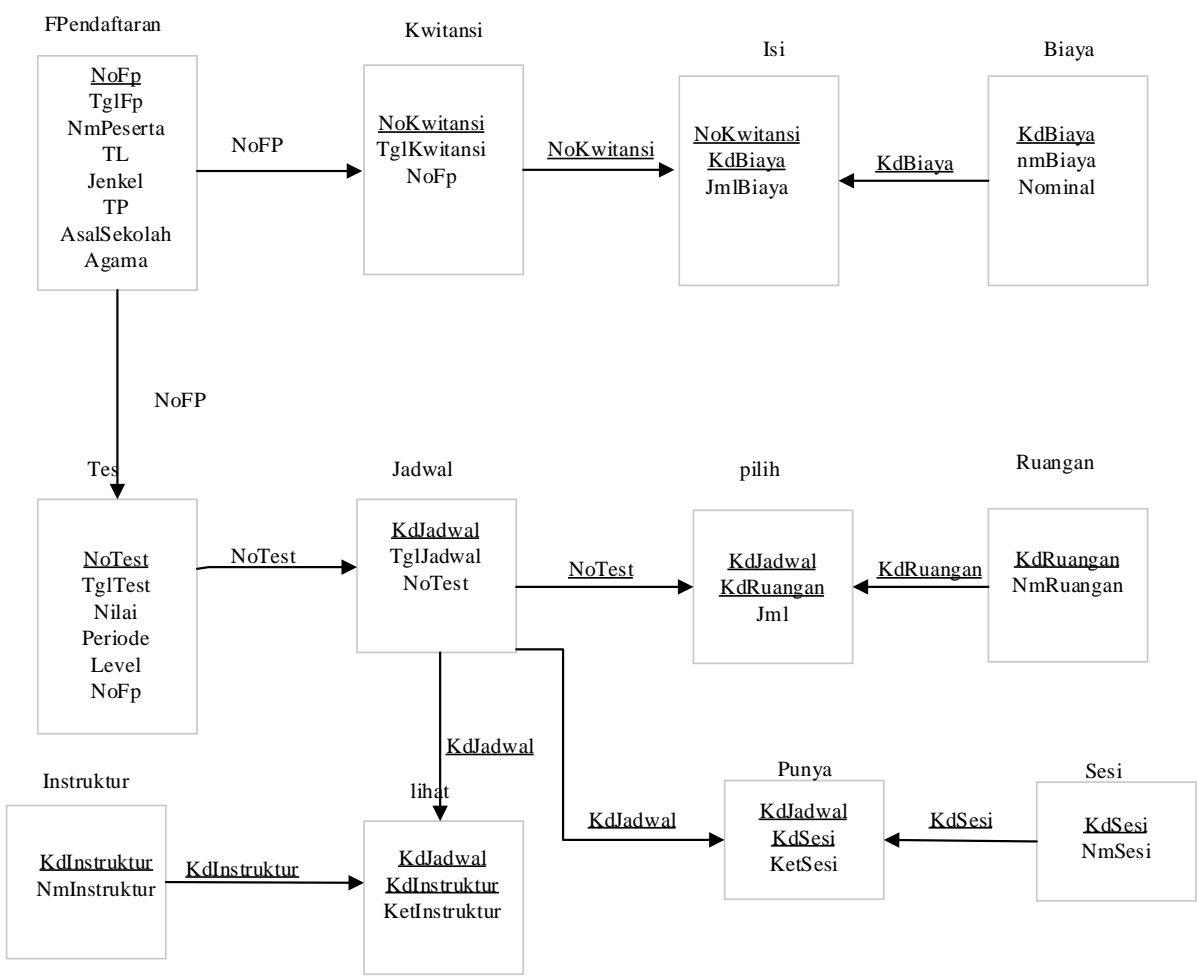

Gambar 7. Logical Record Structure 
Berdasarkan pada proses pembuatan Entity Relationship Diagram sampai dengan Logical Record Structure di atas, dapat dihasilkan tabel-tabel diantaranya adalah :tabel F.Pendaftaran, tabel Kwitansi, tabel isi, tabel biaya, tabel tes, tabel jadawal, tabel ruangan, tabel sesi, tabel instruktur, tabel pilih, tabel punya, dan tabel lihat. Berikut ini adalah skema relasi yang dihasilkan:

a F.Pendaftaran(\#Nofp, TglFp, NmPeserta, TL, Jenkel, TP, Asal Sekolah, Agama)

b Kwitansi(\#NoKwitansi, TglKwitansi, @NoFp)

c Isi(@NoKwitansi, @KdBiaya, JmlBiaya)

d Biaya(\#KdBiaya, nmBiaya, Nominal)

e Test(\#NoTest, Tgltest, Nilai, Periode, Level, NoFp)

f Jadwal(\#KdJadwal, TglJadwal, @NoTest)

g Pilih(@kdJadwal, @KdRuangan,Jml)

h Ruangan(\#KdRuangan, NmRuangan)

i Lihat(@Kdjadwal, @KdInstruktur, KetInstruktur)

j Instruktur(\#KdInstruktur, NmInstruktur)

k Punya(@Kdjadwal, @KdSesi, KetSesi)

1 Sesi(\#kdSesi, NmSesi)

Spesifikasi basis data merupakan uraian terinci dari tiap-tiap relasi/tabel. Berikut ini adalah beberapa spesifikasi basis data yang diusulkan :

a. Nama Tabel : F.Pendaftaran

Primary Key: NoFp

Foreign Key : -

Struktur File :

Tabel 1. Struktur tabel anggota

\begin{tabular}{cccc}
\hline No & Nama Field & Tipe Data & Panjang \\
\hline 1 & NoFp & Char & 5 \\
2 & TglFp & date & 10 \\
3 & NmPeserta & VarChar & 50 \\
4 & TL & Char & 20 \\
5 & TglLahir & date & 10 \\
6 & Jenkel & VarChar & 15 \\
7 & TP & VarChar & 15 \\
8 & AsalSekolah & Varchar & 30 \\
9 & Agama & char & 10 \\
\hline
\end{tabular}

b. Nama Tabel : Kwitansi

Primary Key: NoKwitansi

Foreign Key : NoFp

Struktur File :

Tabel 2. Struktur tabel kwitansi

\begin{tabular}{cccc}
\hline No & Nama Field & Tipe Data & Panjang \\
\hline 1 & NoKwitansi & Char & 5 \\
2 & Tglkwitansi & VarChar & 10 \\
3 & NoFp & Char & 5
\end{tabular}

c. Nama Tabel : Isi

Primary Key: NoKwitansi+KdBiaya

Foreign Key : NoKwitansi+KdBiaya

Struktur File :

Tabel 3. Struktur tabel isi

\begin{tabular}{cccc}
\hline No & Nama Field & Tipe Data & Panjang \\
\hline 1 & NoKwitansi & Char & 5 \\
2 & KdBiaya & Char & 5 \\
3 & JmlBiaya & Int & 2 \\
\hline
\end{tabular}


d. Nama Tabel : Biaya

Primary Key: KdBiaya

Foreign Key : -

Struktur File :

Tabel . Struktur tabel biaya

\begin{tabular}{cccc}
\hline No & Nama Field & Tipe Data & Panjang \\
\hline 1 & KdBiaya & Char & 5 \\
2 & NmBiaya & Char & 25 \\
3 & Nominal & Double & 6
\end{tabular}

Dari sistem yang masih menggunakan sistem yang manual dapat dikembangkan menjadi sebuah sistem yang terkomputerisasi, sehingga basis data yang ada dapat mudah untuk diintegrasikan dengan sistem lain yang ada pada Selective English Course tersebut seperti halnya bagian keuangan dan bagianbagian lainnya yang ada pada Selective English Course. Untuk gambaran basis data yang ada agar mudah untuk diintegrasikan dengan sistem lainnya dapat dilihat pada gambar di bawah ini :

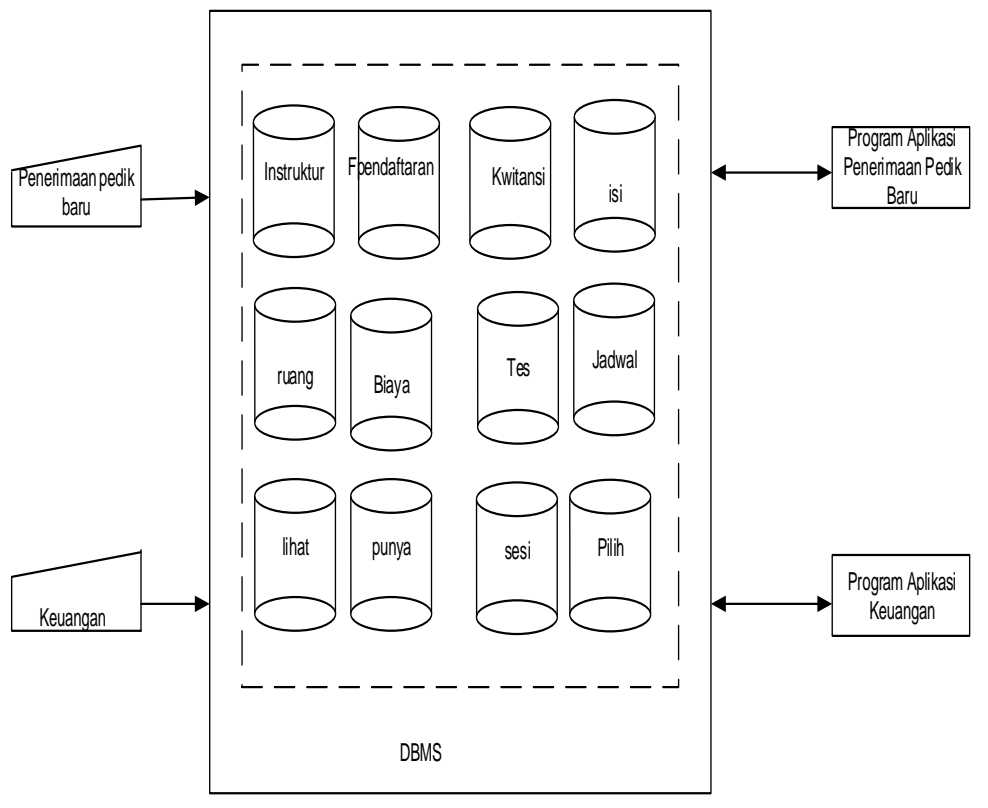

Gambar 8. Aplikasi Database

\section{KESIMPULAN}

Berdasarkan hasil analisa sistem yang berjalan dengan menggunakan Activity Diagram dan proses perancangan basis data dengan menggunakan Entity Rerlationship Diagram yang telah dilakukan, dapat diambil kesimpulan yaitu terdapat tabel-tabel yang dirasakan perlu untuk dikembangkan ke tahapan implementasi nantinya diantaranya meliputi tabel F.Pendaftaran, tabel kwitansi, tabel isi, tabel biaya, tabel tes, tabel jadwal, tabel ruang, tabel sesi, tabel instruktur, tabel pilih, tabel punya, dan tabel lihat yang nantinya akan disimpan dalam sebuah database, sehingga database yang ada nantinya dapat diintegrasikan dengan sistem yang lainnya yang ada pada Selective English Course tersebut.

\section{DAFTAR PUSTAKA}

[1] Putri, Lely. (2014). "Perancangan Sistem Informasi Penerimaan Siswa Baru Pada Sekolah Menengah Kejuruan Negeri 3 Pacitan. “. IJNS - Indonesian Journal on Networking and Security, Volume 3 No 4.

[2] Sutabri, Tata.(2012). "Konsep Sistem Informasi”, Yogyakarta: andi Yogyakarta.

[3] Pahlevi, Said. (2013). "Tujuh Langkah Praktis Pembangunan Basis Data, Jakarta : PT Elex Media Komputindo.

[4] Kusrini. (2007). "Strategi Perancangan dan Pengelolaan Basis Data, Yogyakarya : Andi Yogyakarya.

[5] Al Fatta, Hanif. (2007).” Analisis dan Perancangan Sistem Informasi Untuk Keunggulan Bersaing Perusahaan \& Organisasi Modern”, Yogyakarta: Andi Yogyakarta 